Archive for

Organic Chemistry

Arkivoc 2020, part vii, 228-241

\title{
Synthesis of thiazolyl-based hydroxamic acids as histone deacetylase inhibitors
}

\author{
Yodita Asfaha, Alexander Jan Skerhut, Leandro A. Alves-Avelar, Nadine Horstick-Muche, \\ Beate Lungerich, Stefan Klinken, Matthias U. Kassack,* and Thomas Kurz* \\ Institut für Pharmazeutische und Medizinische Chemie, Heinrich-Heine-Universität Düsseldorf, \\ Universitätsstr.1, 40225 Düsseldorf, Germany \\ Email: thomas.kurz@hhu.de, matthias.kassack@hhu.de
}

Dedicated to Professor Jan Bergman with respect and best wishes for the occasion of his 80th birthday

Received 06-25-2020

Accepted $10-30-2020$

Published on line 11-19-2020

\section{Abstract}

Herein we report the synthesis of 4-phenyl substituted thiazolyl-based hydroxamates as histone deacetylase inhibitors. The synthesis of the target compounds is comprised of a Hantzsch-thiazole reaction, a HATUmediated acylation and a hydroxamic acid synthesis. Preliminary docking results indicated an isozyme selectivity by addressing the lower pocket of HDAC4 with 4-phenyl thiazoles. Surprisingly, this new series of thiazolyl based hydroxamates revealed a moderate HDAC6 inhibitory activity in the low micromolar range. Two of the hydroxamic acids did not show an HDAC4 inhibition up to $100 \mu \mathrm{M}$, whilst a third with a 4-pyridinyl CAP moiety displayed a moderate HDAC4 inhibitory activity in the micromolar range.

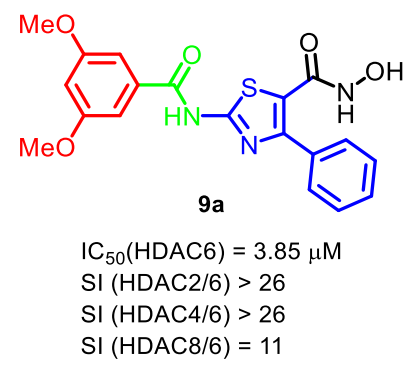

Keywords: Thiazole synthesis, histone deacetylase inhibitors, ester cleavage, hydroxamic acids 


\section{Introduction}

The term epigenetic refers to inheritable changes in gene expression without altering the underlying DNA sequence. ${ }^{1}$ Epigenetic mechanisms are subdivided into four different classes: (1) posttranslational modifications of histones, (2) chemical modifications of DNA (3) chromatin-remodeling complexes, and (4) regulatory non-coding RNAs. An essential post-translational modification is protein acetylation/deacetylation, which is regulated by histone acetyltransferases (HATs) and histone deacetylases (HDACs). The human zinc dependent HDACs are classified into three classes: class I (HDACs 1-3, 8), class II (Ila: HDACs 4, 5, 7, 9; Ilb: HDACs 6,10 ) and class IV (HDAC 11). ${ }^{2}$ Various studies demonstrated that HDACs are overexpressed in a broad spectrum of cancer cells. ${ }^{3-6}$ Their inhibition provides a promising strategy for the development of novel epigenetic anticancer drugs. Until now, the natural product romidepsin and four trichostatin A derived HDAC inhibitors (vorinostat, belinostat, panobinostat, tucidinostat) are approved for the treatment of lymphoma and myeloma (Figure 1). ${ }^{7-12}$ The common pharmacophore model for HDACi consists of the following four elements: a zinc binding group (ZBG), a linker and a connecting unit (CU), that interact with the substrate binding tunnel and a cap, also known as surface recognition domain. ${ }^{13,14}$ According to their ZBG, HDACi can be subdivided into 4 main chemical classes: hydroxamic acids, thiols, carboxylic acids and $o$-amino anilides. ${ }^{15}$

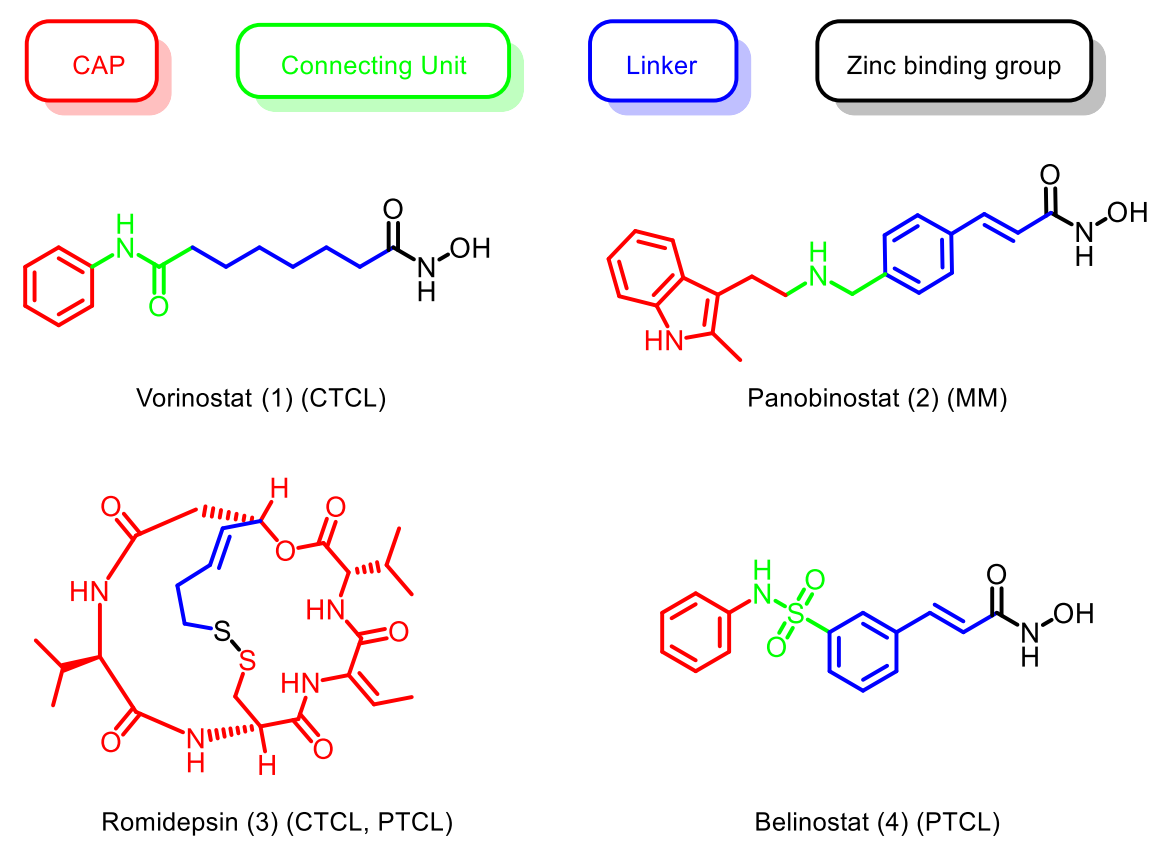

Figure 1. General pharmacophore model of HDACi and chemical structures of FDA approved HDAC inhibitors 1-4 and their indications. CTCL: cutaneous T-cell lymphoma, MM: multiple myeloma, PTCL: peripheral T-cell lymphoma. ${ }^{7-12}$

Thiazoles are privileged structures in medicinal chemistry. Its core scaffold is found in many natural products such as alkaloids, secondary metabolites and cyclopeptides. ${ }^{16}$ The thiazole moiety is also present in several active pharmaceutical ingredients with anticancer, anti-inflammatory, antibacterial, CNS-regulatory, anti-Parkinson, and antidiuretic properties (Figure 2). ${ }^{17-20}$ 
<smiles>CCCNC1CCc2nc(N)sc2C1</smiles>

Pramipexole

Dopamine $\mathrm{D}_{2}$-antagonist

Parkinson's disease \& restless legs syndrome<smiles>Cc1nc(Nc2ncc(C(=O)Nc3c(C)cccc3Cl)s2)cc(N2CCN(CCO)CC2)n1</smiles>

Dasatinib

dual $\mathrm{Abl} / \mathrm{Src}$ tyrosine kinase inhibitor Chronic myeloid leukemia \& Philadelphia chromosome-positive acute lymphoblastic leukemia

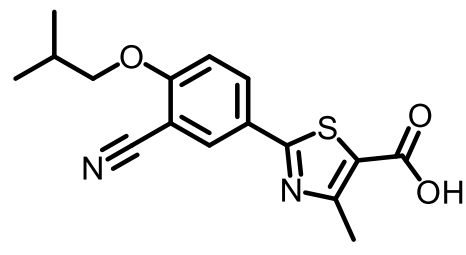

Febuxostat

Xanthine oxidase inhibitor (gout) Chronic gout and hyperuricemia

Figure 2. Selected thiazolyl-based drugs. ${ }^{21-23}$

Initial studies for the develoment of thiazolyl-based HDACi were performed by Anandan et al. (Figure 3). ${ }^{24}$ In the reported $\mathrm{HDACi}$, the thiazole moiety acts as a linker that bridges the ZBG with the cap group. These HDACi displayed in vitro HDAC inhibitory activity in HeLa cell nuclear extracts and antiproliferative effects towards the breast cancer cell line MCF7 in the micromolar range.

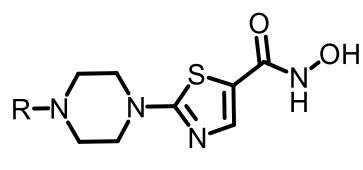

5: $\mathrm{R}=\mathrm{SO}_{2} \mathrm{Ar}$

6: $R=\mathrm{COR}_{1}$

7: $R=R_{2}$<smiles>[R]N1CCN(c2ncc(/C=C/C(=O)NO)s2)CC1</smiles>

8

Figure 3. Thiazolyl-based hydroxamic acids HDACi 5-8. ${ }^{24}$

\section{Results and Discussion}

\section{Design of 4-phenyl substituted thiazolyl hydroxamates as HDAC inhibitors}

Recent studies have shown that HDAC class Ila enzymes might be associated with neurodegenerative diseases and cancer. ${ }^{25-28}$ So far, only trifluoromethyloxadiazoles (TFMO), cyclopropane hydroxamates as well as benzhydryl based class Ila HDAC inhibitors have been reported. In published crystal structures of class Ila HDACs, the so-called lower pocket was identified as a distinctive structural feature. ${ }^{29,30}$ Bürli et al. and Luckhurst et al. showed that tri- and tetrasubstituted cyclopropanes, providing a scaffold with a suitable 3Dgeometry that occupy the lower pocket with their phenyl moiety (Scheme 1, circled in red). ${ }^{25,30}$ Here, we report the synthesis of trisubstituted thiazolyl-based hydroxamates as potential class Ila HDACi. 


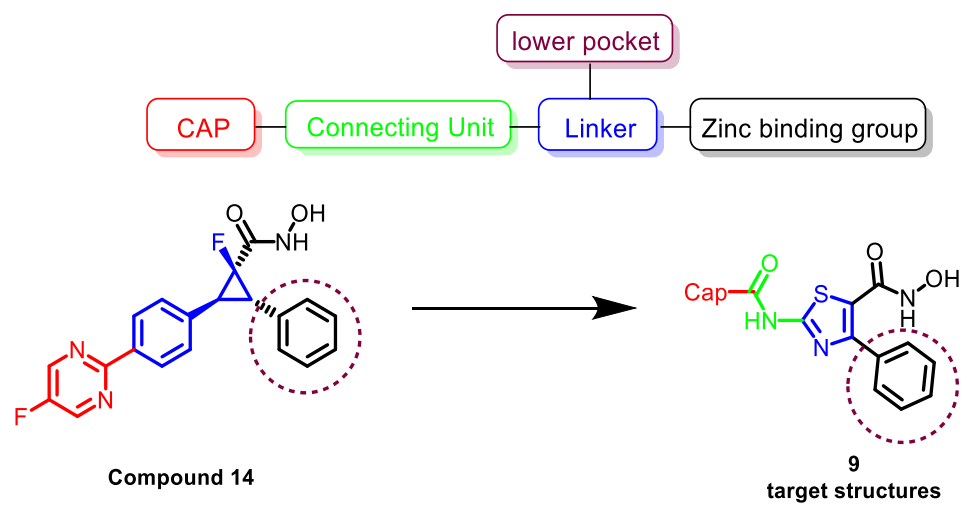

Scheme 1. Pharmacophore model of class Ila selective HDACi (above) and design of target structures as class Ila selective HDAC. ${ }^{30}$

In order to evaluate whether the 4-phenyl-substituent of compound 9a might occupy the lower pocket of class Ila HDACs, we performed docking studies. Molecular docking studies of the thiazole derivative 9a, in various HDAC-isozymes were performed using a previously validated docking protocol employing Autodock 4.2 as docking engine. ${ }^{31}$ 9a, as thiazolyl-based HDACi representative, was docked in HDAC2 (PDB 5IWG) ${ }^{32}$, HDAC8 $(\text { PDB 5CFW) })^{33}$, HDAC4 (PDB 5A2S) ${ }^{30}$ and HDAC6 (PDB 5EDU) $)^{34}$.

The analysis of the docking conformation of compound 9a in HDAC4 suggests that, as envisioned, the hydroxamate moiety of 9 a can coordinate with the zinc cation in a bidentate manner (Figure 4). In addition, the phenyl substituent of 9a occupied the lower pocket in a similar binding mode as the phenyl moiety of compound 14 (Figure 4). The thiazolyl-based hydroxamate 9a did not generate valid docking poses in the other HDACs as no docking pose was observed that showed a complexation of the zinc ion by the hydroxamic acid moiety.

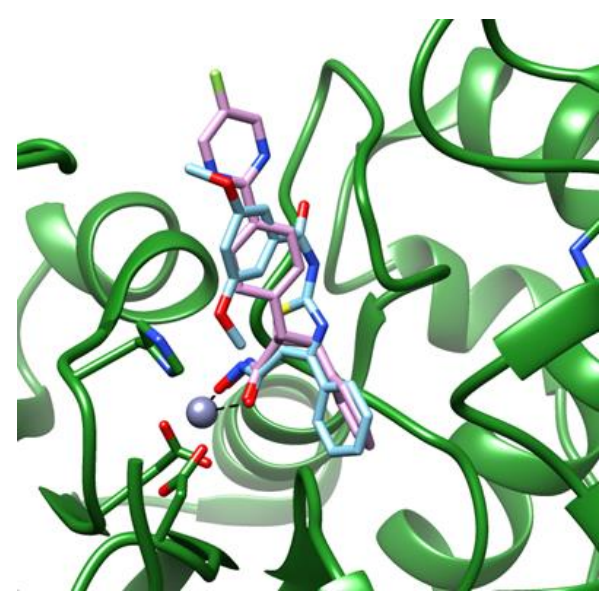

Figure 4. Proposed binding mode of compound 9a (light blue) in HDAC4 (PDB 5A2S) ${ }^{30}$. The docking pose of compound 9a is superimposed with the HDAC4 cocrystallised compound $\mathbf{1 4}$ (pink).

\section{Chemistry}

The starting material of the Hantzsch thiazole synthesis was the $\alpha$-bromoester $\mathbf{1 0}$ that was prepared according to Borowiecki et al.. ${ }^{35}$ After the treatment of $\mathbf{1 0}$ with thiourea, the thiazole $\mathbf{1 1}$ was formed. In the following step, 11 and the respective carboxylic acids were coupled using HATU under basic conditions yielding the corresponding amides 12a-c. The direct hydroxylaminolysis of the esters $\mathbf{1 2 a - c}$ to the corresponding 
hydroxamic acids 9a-c applying various literature procedures did not provide the expected products. ${ }^{36-40}$ Therefore, the hydroxamic acids 9a-c were synthesized by ester hydrolysis and subsequent conversion of the respective carboxylic acids with HATU, DIPEA and hydroxylamine hydrochloride (Scheme 2). The ester hydrolysis was achieved by the addition of an excess of potassium hydroxide. However, the same protocol was unsuccessful when applied for the cleavage of the corresponding ethyl esters. This finding underscores that the hydrolysis depends on the nature of the alkyl substituent of the ester moiety.

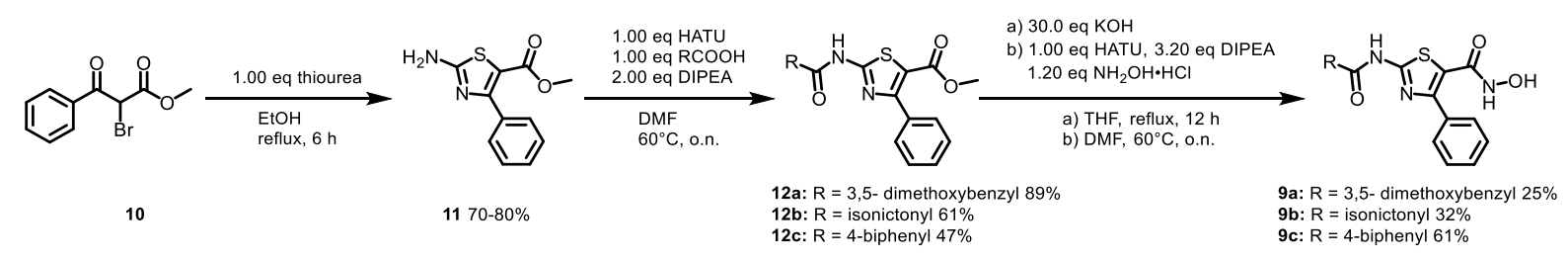

Scheme 2. Synthesis of the target structures 9a-c.

\section{Biological Evaluation}

The synthesised compounds 9a-c were assessed for their antiproliferative activity and for their HDAC inhibitory activity in the human monocytic cell line THP-1 using class-distinguishing substrates (Boc-Lys(Ac)AMC: class I and IIb HDACs; Boc-Lys(TFAc)-AMC: class Ila, HDAC8). The results are depicted in Table 1 with vorinostat as reference compound. Among the tested compounds, $\mathbf{9 b}$ exhibited the highest antiproliferative activity with $61.5 \%$ of growth inhibition at $100 \mu \mathrm{M}$ concentration. The introduction of a 3,5-dimethoxyphenyl (9a) or biphenyl (9c) CAP moiety led to a decreased cytotoxicity with antiproliferative effects below $50 \%$ at $100 \mu \mathrm{M}$. In a whole-cell HDAC inhibition assay using the Boc-Lys(Ac)-AMC-HDAC substrate, all screened hydroxamic acids 9a-c displayed inhibitory activities below $40 \%$ at $100 \mu \mathrm{M}$. However, the cellular HDAC inhibition assay using the Boc-Lys(TFAC)-AMC-HDAC substrate revealed a slightly increased inhibition with over $45 \%$ at $100 \mu \mathrm{M}$ for $9 \mathrm{a}$ and $\mathbf{9 b}$.

Overall there is a good correlation between the antiproliferative activity and the cellular HDAC inhibition. All tested compounds 9a-c showed a moderate cytotoxicity and cellular HDAC inhibition.

For further evaluation, the synthesized compounds 9a-c were screened against recombinant human HDAC2, HDAC4, HDAC6 and HDAC8 (Table 2). Vorinostat was included as a pan-HDACi reference compound. Interestingly, the new thiazolyl-based hydroxamates 9a-c were identified as moderate HDAC6 inhibitors in the low micromolar range. In contrast to our preliminary in-silico data, the hydroxamic acids 9a and 9c displayed no HDAC4 inhibition in the tested concentration range $(\leq 100 \mu \mathrm{M})$. However, the hydroxamic acid $\mathbf{9 b}$ exhibiting a 4-pyridinyl CAP moiety demonstrated a moderate micromolar activity against HDAC4 (IC ${ }_{50}$ (HDAC4) $=48.8 \mu \mathrm{M})$. 
Table 1. Cell viability (MTT assay) and whole-cell HDAC inhibition assay in the human monocytic cell line THP-1

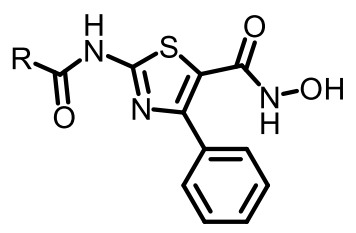

9a-c

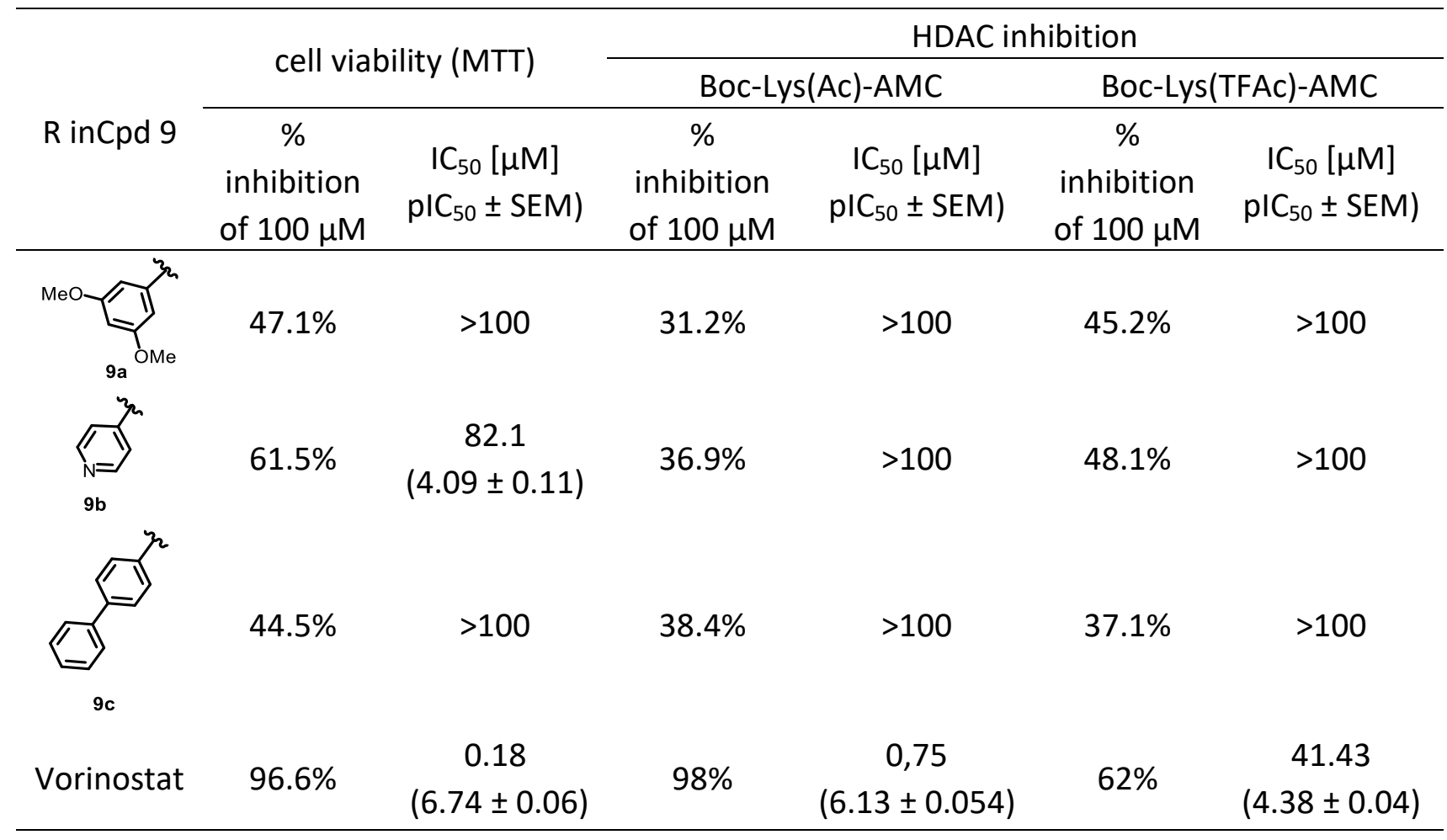

Presented data are calculated from at least two experiments each performed in duplicates. $\mathrm{IC}_{50}$ values were calculated for compounds with an inhibition of more than $50 \%$. Standard deviation of percent inhibition values is less than $14 \%$. Vehicle control was defined as $0 \%$ inhibition. 
Table 2. Inhibitory activity of 9a-c and Vorinostat on recombinant human HDAC2, HDAC4, HDAC6 and HDAC8

\begin{tabular}{|c|c|c|c|c|}
\hline \multirow{2}{*}{ Cpd. } & \multicolumn{4}{|c|}{$\mathrm{IC}_{50}[\mu \mathrm{M}]\left(\mathrm{pI} \mathrm{C}_{50} \pm \mathrm{SEM}\right)$} \\
\hline & HDAC2 & HDAC4 & HDAC6 & HDAC8 \\
\hline $9 \mathrm{a}$ & $>100$ & $>100$ & $\begin{array}{c}3.85 \\
(5.41 \pm 0.04)\end{array}$ & $\begin{array}{c}43.1 \\
(4.37 \pm 0.05)\end{array}$ \\
\hline $9 b$ & $>100$ & $\begin{array}{c}48.8 \\
(4.31 \pm 0.08)\end{array}$ & $\begin{array}{c}3.6 \\
(5.44 \pm 0.04)\end{array}$ & $\begin{array}{c}21.4 \\
(4.67 \pm 0.04)\end{array}$ \\
\hline$\Rightarrow$ & $>100$ & $>100$ & $\begin{array}{c}9.94 \\
(5.0 \pm 0.08)\end{array}$ & $>100$ \\
\hline Vorinostat & $\begin{array}{c}0.096 \\
(7.02 \pm 0.04)\end{array}$ & $\begin{array}{c}96.5 \\
(4.02 \pm 0.05)\end{array}$ & $\begin{array}{c}0.04 \\
(7.63 \pm 0.05)\end{array}$ & $\begin{array}{c}4.44 \\
(5.35 \pm 0.05)\end{array}$ \\
\hline
\end{tabular}

Data shown are from at least two experiments each performed at least as duplicates and the $\mathrm{IC}_{50}$ value of pooled data is reported when $\mathrm{IC}_{50}<100 \mu \mathrm{M}$.

\section{Conclusions}

Histone deacetylases are zinc-dependent metalloproteases that catalyse the removal of acetyl functional groups from lysine residues of both histone and nonhistone proteins. HDACs are involved in a multitude of biological processes e.g. in cell cycle progression, cell survival, apoptosis and differentiation. They are clinically validated targets for the treatment of cancer. Selective HDAC inhibitors may serve as important tools for elucidating the role of specific HDACs in certain diseases. Contrary to our preliminary qualitative in-silico screening, all synthesized compounds 9a-c exhibited a moderate HDAC6 inhibitory activity in the low micromolar range. Only the hydroxamic acid $\mathbf{9 b}$ exhibiting a 4-pyridinyl CAP moiety displayed a moderate micromolar activity against HDAC4 $\left(\mathrm{IC}_{50}(\mathrm{HDAC} 4)=48.8 \mu \mathrm{M}\right)$.

\section{Experimental Section}

General. All chemicals and solvents were purchased from commercial suppliers (Sigma Aldrich, Alfa Aesar, Fluorochem, $\mathrm{TCl}$, abcr and Acros Organics) and used without further purification. All anhydrous reactions were carried out in flame-dried Schlenk-flasks and under argon atmosphere. Dry solvents were used directly from Seal ${ }^{\circledR}$ bottles from Acros Organics. Analytic Thin Layer Chromatography (TLC) was carried out with Macherey 
Nagel precoated silica gel plates (ALUGRAM ${ }^{\circledR}$ Xtra SIL G/UV ${ }_{254}$ ). Detection was achieved with ultraviolet irradiation ( $254 \mathrm{~nm}$ ) and/or staining with potassium permanganate solution ( $9 \mathrm{~g} \mathrm{KMnO}_{4}, 60 \mathrm{~g} \mathrm{~K}_{2} \mathrm{CO}_{3}, 15 \mathrm{~mL}$ of a $5 \%$ aqueous $\mathrm{NaOH}$-solution, and $900 \mathrm{~mL}$ demineralised water). Flash column chromatography was performed with CombiFlashRf200 (TeleDynelsco) with the solvent mixtures specified in the corresponding procedure.

Physical data. Proton $\left({ }^{1} \mathrm{H}\right)$ and carbon $\left({ }^{13} \mathrm{C}\right)$ NMR spectra were recorded on Bruker Avance III - 300, Bruker Avance DRX - 500 or Bruker Avance III - 600. Spectra were referenced to the residual non-deuterated solvent signal ( ${ }^{1} \mathrm{H}-\mathrm{NMR}$ : DMSO- $d_{6}(2.50 \mathrm{ppm}),{ }^{13} \mathrm{C}-\mathrm{NMR}$ : DMSO- $d_{6}(39.52 \mathrm{ppm}) ;{ }^{1} \mathrm{H}-\mathrm{NMR}: \mathrm{CDCl}_{3}(7.26 \mathrm{ppm}),{ }^{13} \mathrm{C}-\mathrm{NMR}$ : $\left.\mathrm{CDCl}_{3}(77.16 \mathrm{ppm})\right)$. Chemical shifts are quoted in parts per million (ppm). Signal patterns are indicated as: singlet $(\mathrm{s})$, doublet $(\mathrm{d})$, triplet $(\mathrm{t})$, quartet $(\mathrm{q})$, or multiplet $(\mathrm{m})$. Coupling constants, $\mathrm{J}$, are measured in $\mathrm{Hz}$. Proton $\left({ }^{1} \mathrm{H}\right)$ and carbon $\left({ }^{13} \mathrm{C}\right)$ NMR spectra were recorded by the NMR-Divisions of the Department of Chemistry (Heinrich-Heine-University Düsseldorf). Electrospray Ionisation (ESI) mass spectra were carried out by the Mass spectrometry-Division of the Heinrich-Heine-University Düsseldorf, using Bruker Daltonics UHRQTOF maXis 4G (Bruker Daltonics). Melting points (mp.) were determined using a Büchi M-565 melting point apparatus and are uncorrected.

Analytical HPLC analysis were carried out on a Knauer HPLC system comprising an Azura P 6.1L pump, an Optimas 800 autosampler, a Fast Scanning Spectro-Photometer K-2600 and Knauer Reversed Phase column (SN: FK36). UV absorption was detected at $254 \mathrm{~nm}$. The solvent gradient table is shown below. The purity of all final compounds was $95 \%$ or higher.

Table 3. The solvent gradient table for analytic HPLC analysis

\begin{tabular}{ccc}
\hline Time / & Water + & ACN + \\
min & $0.1 \%$ TFA & $0.1 \%$ TFA \\
\hline Initial & 90 & 10 \\
0.50 & 90 & 10 \\
20.0 & 0 & 100 \\
30.0 & 0 & 100 \\
31.0 & 90 & 10 \\
40.0 & 90 & 10 \\
\hline
\end{tabular}

Synthesis of methyl 2-bromo-3-oxo-3-phenylpropanoate (10). A solution of methyl 3-oxo-3-propanoate $(2.67 \mathrm{~g}, 15.0 \mathrm{mmol}, 1.00 \mathrm{eq})$ in methanol $(40.0 \mathrm{~mL})$ was cooled to $0{ }^{\circ} \mathrm{C}$ and sodium methoxide (30 wt. \% in methanol, $3.43 \mathrm{~mL}, 18.0 \mathrm{mmol}, 1.20 \mathrm{eq})$ was added dropwise. After stirring for further $5 \mathrm{~min}$, bromine $(0.92$ $\mathrm{mL}, 18.0 \mathrm{mmol}, 1.20 \mathrm{eq})$ in methanol $(20.0 \mathrm{~mL})$ was added dropwise to the reaction. The resulting mixture was stirred overnight at rt. The solvent was removed in vacuo, and the crude solid was resuspended in ethyl acetate. The organic layer was washed with water $(3 \times 25 \mathrm{~mL})$, dried over $\mathrm{Na}_{2} \mathrm{SO}_{4}$ and filtered. After removing the solvent, the crude product was purified by flash column chromatography (prepacked silica cartridge, $n$ hexane/ethyl acetate) to provide 2-bromo-3-oxo-3-phenylpropanoate (10) (2.85 g, $11.1 \mathrm{mmol}, 74 \%)$ as a yellow oil. ${ }^{1} \mathrm{H}$ NMR $\left(300 \mathrm{MHz}\right.$, DMSO- $\left.d_{6}\right) \delta=3.75(\mathrm{~s}, 3 \mathrm{H}), 6.70(\mathrm{~s}, 1 \mathrm{H}), 7.60(\mathrm{t}, J 7.6 \mathrm{~Hz}, 2 \mathrm{H}), 7.69-7.78(\mathrm{~m}, 1 \mathrm{H})$, 8.04 (dd, J 8.4, 1.3 Hz, 2H) ppm. ${ }^{13} \mathrm{C}$ NMR $\left(75 \mathrm{MHz}, \mathrm{DMSO}-d_{6}\right) \delta=46.86,53.67,129.10,133.08,134.58,165.89$, 189.37 ppm. HPLC analysis: $\mathrm{R}_{\mathrm{t}}=12.150 \mathrm{~min}, 98.2 \%$. HRMS $(\mathrm{ESI}+)=$ calcd. for $\mathrm{C}_{10} \mathrm{H}_{10} \mathrm{BrO}_{3}[\mathrm{M}+\mathrm{H}]^{+}=256.9808$, found: 256.9806 . 
Synthesis of methyl 2-amino-4-phenylthiazole-5-carboxylate (11). To a solution of methyl 2-bromo-3-oxo-3phenylpropanoate (10) $(2.53 \mathrm{~g}, 6.70 \mathrm{mmol}, 1.00 \mathrm{eq})$ in methanol $(40.0 \mathrm{~mL})$, thiourea $(0.52 \mathrm{~g}, 6.70 \mathrm{mmol}, 1.00$ eq) was added and the resulting solution was refluxed for $6 \mathrm{~h}$. The solvent was evaporated under reduced pressure and the residue was dissolved in EtOAc, washed with saturated $\mathrm{NaHCO}_{3}$ solution $(3 \times 50 \mathrm{~mL})$ and dried over $\mathrm{Na}_{2} \mathrm{SO}_{4}$. After filtration, the solvent was removed in vacuo to yield the crude product which was purified by flash column chromatography (prepacked silica cartridge, $n$-hexane/ethyl acetate) to provide methyl 2amino-4-phenylthiazole-5-carboxylate (11) $(0.70 \mathrm{~g}, 2.90 \mathrm{mmol}, 43 \%)$ as a yellow solid. M.p.: $183-186^{\circ} \mathrm{C} .{ }^{1} \mathrm{H}$ NMR $\left(300 \mathrm{MHz}\right.$, DMSO- $\left.d_{6}\right) \delta=3.62(\mathrm{~s}, 3 \mathrm{H}), 7.29-7.46(\mathrm{~m}, 3 \mathrm{H}), 7.60-7.68(\mathrm{~m}, 2 \mathrm{H}), 7.86(\mathrm{~s}, 2 \mathrm{H}) \mathrm{ppm} .{ }^{13} \mathrm{C} \mathrm{NMR}$ $\left(75 \mathrm{MHz}, \mathrm{DMSO}-d_{6}\right) \delta=51.40,107.65,127.33,128.69,129.58,134.51,159.02,161.53,169.89$ ppm. HPLC analysis: $\mathrm{R}_{t}=7.533 \mathrm{~min}, 97.2 \%$. HRMS $(E S I+)=$ calcd. for $\mathrm{C}_{11} \mathrm{H}_{11} \mathrm{~N}_{2} \mathrm{O}_{2} \mathrm{~S}[\mathrm{M}+\mathrm{H}]^{+}=235.0536$, found: 235.0535 .

\section{General procedure 1. HATU-coupling}

For the synthesis of the amides $12 a-c, 1.00$ eq of the respective carboxylic acid was dissolved in dry DMF (0.1 $\mathrm{mmol} / \mathrm{mL}$ ) and $1.00 \mathrm{eq} \mathrm{HATU}$ and 2.00 eq DIPEA were added. After stirring for $15 \mathrm{~min}$ at rt, methyl 2-amino-4phenylthiazole-5-carboxylate (11) (1.00 eq) was added and the resulting mixture was stirred for $16 \mathrm{~h}$ at $60{ }^{\circ} \mathrm{C}$. The solvent was removed in vacuo and the residue was diluted with EtOAc. The organic layer was washed with saturated $\mathrm{NaHCO}_{3}(3 \times 50 \mathrm{~mL})$, brine $(1 \times 50 \mathrm{~mL})$, dried over $\mathrm{Na}_{2} \mathrm{SO}_{4}$ and filtered. After the removal of the solvent, the crude product was purified by flash column chromatography (prepacked silica cartridge, $n$-hexane/ethyl acetate) to provide the amides 12a-c.

Methyl 2-(3,5-dimethoxybenzamido)-4-phenyl-thiazole-5-carboxylate (12a). 3,5-Dimethoxybenzoic acid (1.01 $\mathrm{g}, 5.50 \mathrm{mmol}, 1.00 \mathrm{eq}$ ) was subjected to General Procedure 1. The crude product was purified by flash column chromatography (n-hexane/EtOAc) to furnish methyl 2-(3,5-dimethoxybenzamido)-4-phenyl-thiazole-5carboxylate (12a) $(1.95 \mathrm{~g}, 4.90 \mathrm{mmol}, 98 \%)$ as a white solid. M.p.: $170-174^{\circ} \mathrm{C} .{ }^{1} \mathrm{H} \mathrm{NMR}\left(300 \mathrm{MHz}, \mathrm{DMSO}-d_{6}\right) \delta=$ $3.74(\mathrm{~s}, 3 \mathrm{H}), 3.83(\mathrm{~s}, 6 \mathrm{H}), 6.76(\mathrm{t}, J 2.2 \mathrm{~Hz}, 1 \mathrm{H}), 7.33(\mathrm{~d}, J 2.3 \mathrm{~Hz}, 2 \mathrm{H}), 7.41-7.51(\mathrm{~m}, 3 \mathrm{H}), 7.74(\mathrm{dd}, J 6.6,3.0 \mathrm{~Hz}$, $2 \mathrm{H}), 13.15(\mathrm{~s}, 1 \mathrm{H}) \mathrm{ppm} .{ }^{13} \mathrm{C}$ NMR $\left(75 \mathrm{MHz}, \mathrm{DMSO}-d_{6}\right) \delta=51.90,55.59,105.49,106.02,127.55,128.91,129.63$, $133.15,134.01,155.96,160.19,160.52,161.80,165.33$ ppm. HPLC analysis: $R_{t}=15.883 \mathrm{~min},>99 \%$. HRMS $\left(E S I^{+}\right)$: calcd. for $\mathrm{C}_{20} \mathrm{H}_{19} \mathrm{~N}_{2} \mathrm{O}_{5} \mathrm{~S}[\mathrm{M}+\mathrm{H}]^{+}=399.1009$, found: 399.1008 .

Methyl 2-(isonicotinamido)-4-phenylthiazole-5-carboxylate (12b). Isonicotinic acid (373 mg, $3.00 \mathrm{mmol}, 1.00$ eq) was subjected to General Procedure 1. The crude product was purified by flash column chromatography ( $n$-hexane/EtOAc) to furnish methyl 2-(isonicotinamido)-4-phenylthiazole-5-carboxylate (12b) (0.62 g, 1.80 mmol, 61\%) as a white solid. M.p.: $225-229^{\circ} \mathrm{C} .{ }^{1} \mathrm{H}$ NMR $\left(300 \mathrm{MHz}, \mathrm{DMSO}-d_{6}\right) \delta=3.73(\mathrm{~s}, 3 \mathrm{H}), 7.30-7.53(\mathrm{~m}$, $3 \mathrm{H}), 7.69-7.79(\mathrm{~m}, 2 \mathrm{H}), 7.97-8.04(\mathrm{~m}, 2 \mathrm{H}), 8.75-8.85(\mathrm{~m}, 2 \mathrm{H}), 13.47(\mathrm{~s}, 1 \mathrm{H}) \mathrm{ppm} .{ }^{13} \mathrm{C} \mathrm{NMR}(75 \mathrm{MHz}$, DMSO$\left.d_{6}\right) \delta=52.03,115.13,121.81,127.62,129.04,129.69,133.78,138.51,150.46,155.87,159.81,161.68,164.67$ ppm. HPLC analysis: $\mathrm{R}_{t}=9.667 \mathrm{~min},>99 \%$. HRMS $\left(\mathrm{ESI}^{+}\right)$: calcd. for $\mathrm{C}_{17} \mathrm{H}_{14} \mathrm{~N}_{3} \mathrm{O}_{3} \mathrm{~S}[\mathrm{M}+\mathrm{H}]^{+}=340.0750$, found: 340.0753.

Methyl 2-([1,1'-biphenyl]-4-carboxamido)-4-phenylthiazole-5-carboxylate (12c). Biphenyl-4-carboxylic acid (595 mg, $3.00 \mathrm{mmol}, 1.00 \mathrm{eq}$ ) was subjected to General Procedure 1. The crude product was purified by flash column chromatography (n-hexane/EtOAc) to furnish methyl 2-([1,1'-biphenyl]-4-carboxamido)-4phenylthiazole-5-carboxylate (12c) $(0.58 \mathrm{~g}, 1.40 \mathrm{mmol}, 47 \%)$ as a white solid. M.p.: $267-270^{\circ} \mathrm{C} .{ }^{1} \mathrm{H} N M R(600$ $\left.\mathrm{MHz}, \mathrm{DMSO}-d_{6}\right) \delta=3.75(\mathrm{~s}, 3 \mathrm{H}), 7.41-7.47(\mathrm{~m}, 4 \mathrm{H}), 7.51(\mathrm{dd}, J 8.4,6.9 \mathrm{~Hz}, 2 \mathrm{H}), 7.71-7.82(\mathrm{~m}, 4 \mathrm{H}), 7.83-$ $7.90(\mathrm{~m}, 2 \mathrm{H}), 8.19-8.27(\mathrm{~m}, 2 \mathrm{H}), 13.24(\mathrm{~s}, 1 \mathrm{H}) \mathrm{ppm} .{ }^{13} \mathrm{C} N M R\left(151 \mathrm{MHz}, \mathrm{DMSO}-d_{6}\right) \delta=52.01,114.70,126.80$, $126.99,127.63,128.43,129.00,129.10,129.12,129.70,130.12,134.01,138.74,144.40,156.06,160.34$, 161.85, 165.56 ppm. HPLC analysis: $\mathrm{R}_{t}=17.983 \mathrm{~min}, 98.3 \%$. HRMS (ESI ${ }^{+}$): calcd. for $\mathrm{C}_{24} \mathrm{H}_{19} \mathrm{~N}_{2} \mathrm{O}_{3} \mathrm{~S}[\mathrm{M}+\mathrm{H}]^{+}=$ 415.1111, found: 415.1114 . 


\section{General procedure 2: Methyl ester hydrolysis}

For the synthesis of the carboxylic acids 13a-c, 1.00 eq of the methyl ester 12a-c was dissolved in THF (0.1 $\mathrm{mmol} / \mathrm{mL}$ ) and 30.0 eq potassium hydroxide was added. The resulting mixture was refluxed for $16 \mathrm{~h}$. The solvent was removed in vacuo and the residue was resuspended with EtOAc. The organic layer was washed with saturated $\mathrm{NaHCO}_{3}(3 \times 50 \mathrm{~mL})$. The combined aqueous phases were acidified $(\mathrm{pH}=2-3)$ and the resulting precipitate (product) was filtered off and washed with water.

2-(3,5-Dimethoxybenzamido)-4-phenylthiazole-5-carboxylic acid (13a). Methyl 2-(3,5-dimethoxybenzamido)4-phenyl-thiazole-5-carboxylate (12a) $(0.51 \mathrm{~g}, 1.28 \mathrm{mmol}, 1.00 \mathrm{eq})$ was subjected to General Procedure 2. The acid $13 \mathrm{a}(0.27 \mathrm{~g}, 0.71 \mathrm{mmol}, 55 \%)$ was obtained as a white solid. M.p.: $187-191^{\circ} \mathrm{C} .{ }^{1} \mathrm{H} \mathrm{NMR}(600 \mathrm{MHz}, \mathrm{DMSO}-$ $\left.d_{6}\right) \delta=3.83(\mathrm{~s}, 6 \mathrm{H}), 6.76(\mathrm{t}, J 2.3 \mathrm{~Hz}, 1 \mathrm{H}), 7.33(\mathrm{~d}, J 2.3 \mathrm{~Hz}, 2 \mathrm{H}), 7.39-7.45(\mathrm{~m}, 3 \mathrm{H}), 7.71-7.78(\mathrm{~m}, 2 \mathrm{H}), 13.05$ $(\mathrm{s}, 2 \mathrm{H}) \mathrm{ppm} .{ }^{13} \mathrm{C}$ NMR $(151 \mathrm{MHz}$, DMSO-d $) \delta=55.62,105.46,105.94,116.78,127.53,128.73,129.78,133.24$, $134.25,155.10,159.73,160.49,162.83,165.22$ ppm. HPLC analysis: $R_{t}=13.00 \mathrm{~min}, 96.4 \%$. HRMS (ESI+) $=$ calcd. for $\mathrm{C}_{19} \mathrm{H}_{17} \mathrm{~N}_{2} \mathrm{O}_{5} \mathrm{~S}[\mathrm{M}+\mathrm{H}]^{+}=385.0853$, found: 385.0852 .

2-(Isonicotinamido)-4-phenylthiazole-5-carboxylic acid (13b). Methyl 2-(isonicotinamido)-4-phenylthiazole-5carboxylate (12b) (338 mg, $1.04 \mathrm{mmol}, 1.00 \mathrm{eq})$ was subjected to General Procedure 2. The acid 13b (228 mg, $0.70 \mathrm{mmol}, 67 \%)$ was obtained as a white solid. M.p.: $246-250^{\circ} \mathrm{C} .{ }^{1} \mathrm{H} \mathrm{NMR}\left(300 \mathrm{MHz}, \mathrm{DMSO}-d_{6}\right) \delta=1.23(\mathrm{t}, J$ $7.1 \mathrm{~Hz}, 3 \mathrm{H}), 4.22(\mathrm{q}, J 7.1 \mathrm{~Hz}, 2 \mathrm{H}), 7.40-7.55(\mathrm{~m}, 3 \mathrm{H}), 7.68-7.81(\mathrm{~m}, 2 \mathrm{H}), 7.98-8.08(\mathrm{~m}, 2 \mathrm{H}), 8.78-8.90(\mathrm{~m}$, $2 \mathrm{H}), 13.50(\mathrm{~s}, 1 \mathrm{H}) \mathrm{ppm} .{ }^{13} \mathrm{C}$ NMR $\left(75 \mathrm{MHz}, \mathrm{DMSO}-d_{6}\right) \delta=13.91,60.85,115.62,121.78,127.56,128.99,129.71$, 133.80, 138.50, 150.46, 155.66, 159.74, 161.24, 164.64 ppm. HPLC analysis: $R_{t}=6.883 \mathrm{~min}, 98.4 \%$. HRMS $\left(E S I^{+}\right)$: calcd. for $\mathrm{C}_{16} \mathrm{H}_{12} \mathrm{~N}_{3} \mathrm{O}_{3} \mathrm{~S}[\mathrm{M}+\mathrm{H}]^{+}=326.0594$, found: 326.0597 .

2-([1,1'-Biphenyl]-4-carboxamido)-4-phenylthiazole-5-carboxylic acid (13c). Methyl 2-[(1,1'-biphenyl]-4carboxamido]-4-phenylthiazole-5-carboxylate (12c) $(0.35 \mathrm{~g}, 0.84 \mathrm{mmol}, 1.00 \mathrm{eq})$ was subjected to General Procedure 2. The acid $13 \mathrm{c}(0.31 \mathrm{~g}, 0.77 \mathrm{mmol}, 92 \%)$ was obtained as a white solid. M.p.: $248{ }^{\circ} \mathrm{C}($ decomp. $) .{ }^{1} \mathrm{H}$ NMR $\left(600 \mathrm{MHz}\right.$, DMSO- $\left.d_{6}\right) \delta=7.40-7.46(\mathrm{~m}, 4 \mathrm{H}), 7.51(\mathrm{t}, J 7.7 \mathrm{~Hz}, 2 \mathrm{H}), 7.72-7.81(\mathrm{~m}, 4 \mathrm{H}), 7.85-7.89(\mathrm{~m}$, $2 \mathrm{H}), 8.22-8.26(\mathrm{~m}, 2 \mathrm{H}), 13.13(\mathrm{~s}, 1 \mathrm{H}) \mathrm{ppm} .{ }^{13} \mathrm{C}$ NMR $\left(151 \mathrm{MHz}, \mathrm{DMSO}-d_{6}\right) \delta=126.83,127.01,127.56,128.44$, $128.77,129.09,129.12,129.81,138.78,144.39,162.86,165.44 \mathrm{ppm}$.

HPLC analysis: $\mathrm{R}_{t}=14.933 \mathrm{~min}, 92.0 \%$. HRMS $(\mathrm{ESI}+)=$ calcd. for $\mathrm{C}_{23} \mathrm{H}_{17} \mathrm{~N}_{2} \mathrm{O}_{3} \mathrm{~S}[\mathrm{M}+\mathrm{H}]^{+}=401.0954$, found: 401.0953.

\section{General procedure 3. Hydroxamic acid formation}

For the synthesis of the hydroxamic acids $9 a-c, 1.00$ eq of the respective carboxylic acid 13a-c was dissolved in dry DMF (0.1 mmol/mL), 1.00 eq HATU and 3.20 eq DIPEA were added. After stirring for $15 \mathrm{~min}$ at rt, 1.20 eq hydroxylamine hydrochloride was added and the resulting mixture was stirred for further $16 \mathrm{~h}$ at $60{ }^{\circ} \mathrm{C}$. The reaction mixture was then poured into water and the resulting participate was then filtered and washed with aqueous $\mathrm{HCl}$-solution $(\mathrm{pH}=4)$ and water. The crude product was purified by flash column chromatography (prepacked silica cartridge, DCM/30\% methanol in DCM) to provide the corresponding hydroxamic acids.

2-(3,5-Dimethoxybenzamido)-N-hydroxy-4-phenylthiazole-5-carboxamide(9a). 2-(3,5-Dimethoxybenzamido)4-phenylthiazole-5-carboxylic acid (13a) $(199 \mathrm{mg}, 0.50 \mathrm{mmol}, 1.00 \mathrm{eq})$ was subjected to General Procedure 3. The hydroxamic acid 9a (50.0 mg, $0.12 \mathrm{mmol}, 25 \%)$ was obtained as a white solid. M.p. $225{ }^{\circ} \mathrm{C}$ (decomp.) ${ }^{1} \mathrm{H}$ NMR $\left(300 \mathrm{MHz}\right.$, DMSO- $\left.d_{6}\right) \delta=3.84(\mathrm{~s}, 6 \mathrm{H}), 6.76(\mathrm{~s}, 1 \mathrm{H}), 7.34(\mathrm{~d}, J 2.2 \mathrm{~Hz}, 2 \mathrm{H}), 7.38-7.52(\mathrm{~m}, 3 \mathrm{H}), 7.77(\mathrm{~d}, J 6.8$ $\mathrm{Hz}, 2 \mathrm{H}), 9.28(\mathrm{~s}, 1 \mathrm{H}), 11.07(\mathrm{~s}, 1 \mathrm{H}), 12.98(\mathrm{~s}, 1 \mathrm{H}) \mathrm{ppm} .{ }^{13} \mathrm{C} N M R\left(75 \mathrm{MHz}, \mathrm{DMSO}-d_{6}\right) \delta=55.61,105.35,105.96$, $128.13,128.28,128.70,129.70,129.71,133.40,134.10,154.81,160.52,161.78,165.01 . H P L C$ analysis: $R_{t}=t=$ $10.383 \mathrm{~min}, 95.0 \%$. HRMS $(\mathrm{ESI}+)=$ calcd. for $\mathrm{C}_{19} \mathrm{H}_{18} \mathrm{~N}_{3} \mathrm{O}_{5} \mathrm{~S}[\mathrm{M}+\mathrm{H}]^{+}=400.0962$, found: 400.0960 . 
$\mathbf{N}$-Hydroxy-2-(isonicotinamido)-4-phenylthiazole-5-carboxamide (9b). 2-(Isonicotinamido)-4-phenylthiazole5-carboxylic acid (13b) (595 mg, $1.83 \mathrm{mmol}, 1.00 \mathrm{eq}$ ) was subjected to General Procedure 3. The hydroxamic acid $9 \mathrm{~b}(0.200 \mathrm{~g}, 0.59 \mathrm{mmol}, 32 \%)$ was obtained as an orange solid. M.p. $210-214^{\circ} \mathrm{C} .{ }^{1} \mathrm{H} \mathrm{NMR}(300 \mathrm{MHz}$, DMSO- $\left.d_{6}\right) \delta=7.42(\mathrm{dq}, J 13.5,6.8 \mathrm{~Hz}, 3 \mathrm{H}), 7.76(\mathrm{~d}, J 7.3 \mathrm{~Hz}, 2 \mathrm{H}), 8.01(\mathrm{~d}, J 5.2 \mathrm{~Hz}, 2 \mathrm{H}), 8.82(\mathrm{~d}, J 5.1 \mathrm{~Hz}, 2 \mathrm{H})$, $9.34(\mathrm{~s}, 1 \mathrm{H}), 11.12(\mathrm{~s}, 1 \mathrm{H}) \mathrm{ppm} .{ }^{13} \mathrm{C} \mathrm{NMR}\left(75 \mathrm{MHz}, \mathrm{DMSO}-d_{6}\right) \delta=117.92,121.95,128.40,128.59,133.95$, 138.88, 150.59, 156.94, 164.49 ppm. HPLC analysis: $R_{t}=4.817 \mathrm{~min}, 97.3 \%$. HRMS $(E S I+)=$ calcd. for $\mathrm{C}_{16} \mathrm{H}_{13} \mathrm{~N}_{4} \mathrm{O}_{3} \mathrm{~S}[\mathrm{M}+\mathrm{H}]^{+}=341.0703$, found: 304.0706 .

2-([1,1'-Biphenyl]-4-carboxamido)-N-hydroxy-4-phenylthiazole-5-carboxamide $\quad$ (9c). 2-([1,1'-Biphenyl]-4carboxamido)-4-phenylthiazole-5-carboxylic acid (13c) $(260 \mathrm{mg}, 0.65 \mathrm{mmol}, 1.00 \mathrm{eq}$ ) was subjected to General Procedure 3. The hydroxamic acid $9 \mathrm{c}(0.165 \mathrm{~g}, 0.40 \mathrm{mmol}, 61 \%)$ was obtained as a white solid. M.p. $225{ }^{\circ} \mathrm{C}$ (decomp.) ${ }^{1} \mathrm{H}$ NMR $\left(600 \mathrm{MHz}, \mathrm{DMSO}-d_{6}\right) \delta=7.38-7.47(\mathrm{~m}, 4 \mathrm{H}), 7.52(\mathrm{t}, J 7.6 \mathrm{~Hz}, 2 \mathrm{H}), 7.79(\mathrm{~d}, J 7.6 \mathrm{~Hz}, 4 \mathrm{H})$, $7.88(\mathrm{~d}, J 8.0 \mathrm{~Hz}, 2 \mathrm{H}), 8.25(\mathrm{~d}, J 8.1 \mathrm{~Hz}, 2 \mathrm{H}), 9.29(\mathrm{~s}, 1 \mathrm{H}), 11.09(\mathrm{~s}, 1 \mathrm{H}), 13.05$ (s, 1H) ppm.

${ }^{13} \mathrm{C}$ NMR $\left(151 \mathrm{MHz}\right.$, DMSO- $\left.d_{6}\right) \delta=126.81,127.00,127.55,128.22,128.32,128.41,129.02,129.11,130.26$, 134.05, 138.79, 144.30, 148.59, 157.20, 159.67, 165.16 ppm. HPLC analysis : $R_{t}=t=12.633 \mathrm{~min}, 95.7 \%$. HRMS $(\mathrm{ESI}+)=$ calcd. for $\mathrm{C}_{23} \mathrm{H}_{18} \mathrm{~N}_{3} \mathrm{O}_{3} \mathrm{~S} \mathrm{O}_{3}[\mathrm{M}+\mathrm{H}]^{+}=416.1063$, found: 416.1055 .

\section{Acknowledgements}

YA, AJS, MUK, and TK gratefully acknowledge support from the Deutsche Forschungsgemeinschaft (DFG) for grant number KA 1942/1-1 to MUK and grant number KU 1577/2-1 to TK, and the support from the DFG research training group 270650915/GRK2158. We further acknowledge the CHDI Foundation Inc. for providing the compound CHDI-00390576-0000-004.

\section{Supplementary Material}

The performed docking studies and the experimental procedures for the biological evaluation are provided as supplementary material.

\section{References}

1. Bird, A. Nature 2007, 447 (7143), 396-398.

https://doi.org/10.1038/nature05913

2. Fischle, W.; Dequiedt, F.; Hendzel, M. J.; Guenther, M. G.; Lazar, M. A.; Voelter, W.; Verdin, E. Mol. Cell 2002, 9, 45-57.

https://10.1016/s1097-2765(01)00429-4

3. Gryder, B. E.; Sodji, Q. H.; Oyelere, A. K. Future Med. Chem. 2012, 4, 505-524.

https://doi.org/10.4155/fmc.12.3

4. Witt, O.; Deubzer, H. E.; Milde, T.; Oehme, I. Cancer Lett. 2009, 277, 8-21.

ttps://doi.org/10.1016/i.canlet.2008.08.016

5. Ropero, S.; Esteller, M. Mol. Oncol. 2007, 1, 19-25.

https://doi.org/10.1016/i.molonc.2007.01.001 
6. Jung, M., Curr. Med. Chem. 2001, 8, 1505-1511.

https://doi.org/10.2174/0929867013372058

7. Marks, P. A.; Breslow, R., Nat. Biotechnol. 2007, 25, 84-90.

https://doi.org/10.1038/nbt1272

8. Duvic, M.; Talpur, R.; Ni, X.; Zhang, C.; Hazarika, P.; Kelly, C.; Chiao, J. H.; Reilly, J. F.; Ricker, J. L.; Richon, V. M.; Frankel, S. R. Blood 2007, 109, 31-39.

https://doi.org/10.1182/blood-2006-06-025999

9. Minucci, S.; Pelicci, P. G. Nat. Rev. Cancer 2006, 6, 38-51.

https://doi.org/10.1038/nrc1779

10. Richon, V. M.; Emiliani, S.; Verdin, E.; Webb, Y.; Breslow, R.; Rifkind, R. A.; Marks, P. A. Proc. Natl. Acad. Sci. 1998, 95, 3003-3007.

https://doi.org/10.1073/pnas.95.6.3003

11. Hose, C. D.; Petersen, K. D.; Shoemaker, R. H.; Kondapaka, S.; Pezzoli, P.; Monforte, J.; Monks, A.; Sehested, M.; Vansant, G. Anticancer. Drugs 2009, 20, 682-692.

https://doi.org/10.1097/cad.0b013e32832e14e1

12. Atadja, P. Cancer Lett. 2009, 280, 233-241.

https://doi.org/10.1016/i.canlet.2009.02.019

13. Melesina, J.; Praetorius, L.; Simoben, C. V.; Robaa, D.; Sippl, W. Future Med. Chem. 2018, 10, $1537-1540$. https://doi.org/10.4155/fmc-2018-0125

14. Bolden, J. E.; Peart, M. J.; Johnstone, R. W. Nat. Rev. Drug Discov. 2006, 5, 769-784. https://doi.org/10.1038/nrd2133

15. Seidel, C.; Schnekenburger, M.; Dicato, M.; Diederich, M. Genes Nutr. 2012, 7 (3), 357-367. https://doi.org/10.1007/s12263-012-0283-9

16. Mishra, R.; Sharma, P. K.; Verma, P. K.; Tomer, I.; Mathur, G.; Dhakad, P. K. J. Heterocycl. Chem. 2017, 54, 2103-2116.

https://doi.org/10.1002/ihet.2827

17. Rashad, A. E.; Mahmoud, A. E.; Ali, M. M., Eur. J. Med. Chem. 2011, 46, 1019-1026. https://doi.org/10.1016/i.ejmech.2011.01.013

18. Karegoudar, P.; Karthikeyan, M. S.; Prasad, D. J.; Mahalinga, M.; Holla, B. S.; Kumari, N. S. Eur. J. Med. Chem. 2008, 43, 261-267. https://doi.org/10.1016/i.ejmech.2007.03.014

19. Cukurovali, A.; Yilmaz, I.; Gur, S.; Kazaz, C. Eur. J. Med. Chem. 2006, 41, 201-207. https://doi.org/10.1016/i.ejmech.2005.01.013

20. Wu, X.; Kassie, F.; Mersch-Sundermann, V., Mutat. Res. - Rev. Mutat. Res. 2005, 589, 81-102. https://doi.org/10.1016/j.mrrev.2004.11.001

21. Barone, P.; Poewe, W.; Albrecht, S.; Debieuvre, C.; Massey, D.; Rascol, O.; Tolosa, E.; Weintraub, D. Lancet Neurol. 2010, 9, 573-580.

https://doi.org/10.1016/S1474-4422(10)70106-X

22. Mukaihara, K.; Tanabe, Y.; Kubota, D.; Akaike, K.; Hayashi, T.; Mogushi, K.; Hosoya, M.; Sato, S.; Kobayashi, E.; Okubo, T.; Kim, Y.; Kohsaka, S.; Saito, T.; Kaneko, K.; Suehara, Y. PLoS One 2017, 12, e0185321. https://doi.org/10.1371/journal.pone.0185321

23. White, W. B.; Chohan, S.; Dabholkar, A.; Hunt, B.; Jackson, R. Am. Heart J. 2012, 164, 14-20. https://doi.org/10.1016/j.ahj.2012.04.011 
24. Anandan, S.; Ward, J. S.; Brokx, R. D.; Denny, T.; Bray, M. R.; Patel, D. V; Xiao, X. Bioorg. Med. Chem. Lett. 2007, 17, 5995-5999.

https://doi.org/10.1016/i.bmcl.2007.07.050

25. Bürli, R. W.; Luckhurst, C. A.; Aziz, O.; Matthews, K. L.; Yates, D.; Lyons, K. A.; Beconi, M.; McAllister, G.; Breccia, P.; Stott, A. J.; et al. J. Med. Chem. 2013, 56, 9934-9954.

https://doi.org/10.1021/jm4011884

26. Hobara, T.; Uchida, S.; Otsuki, K.; Matsubara, T.; Funato, H.; Matsuo, K.; Suetsugi, M.; Watanabe, Y. J. Psychiatr. Res. 2010, 44 (5), 263-270.

https://doi.org/10.1016/i.jpsychires.2009.08.015

27. Sung, Y. M.; Lee, T.; Yoon, H.; DiBattista, A. M.; Song, J. M.; Sohn, Y.; Moffat, E. I.; Turner, R. S.; Jung, M.; Kim, J.; Hoe, H.-S. Exp. Neurol. 2013, 239, 192-201.

https://doi.org/10.1016/j.expneurol.2012.10.005

28. Tsankova, N.; Renthal, W.; Kumar, A.; Nestler, E. J. Nat. Rev. Neurosci. 2007, 8, 355-367. https://doi.org/10.1038/nrn2132

29. Lobera, M.; Madauss, K. P.; Pohlhaus, D. T.; Wright, Q. G.; Trocha, M.; Schmidt, D. R.; Baloglu, E.; Trump, R. P.; Head, M. S.; Hofmann, G. A.; Murray-Thompson,M.; Schwartz, B.; Chakravorty, S.; Wu, Z.; Mander, P. K.; Kruidenier, L.; Reid, R. A.; Burkhardt, W.; Turunen, B. J.; Rong, J. X.; Wagner, C.; Moyer, M. B.; Wells, C.; Hong, X.; Moore, J. T.; Williams, J. D.; Soler, D.; Ghosh, S.; Nolan, M. A. Nat. Chem. Biol. 2013, 9, 319-325. https://doi.org/10.1038/nchembio.1223

30. Luckhurst, C. A.; Breccia, P.; Stott, A. J.; Aziz, O.; Birch, H. L.; Bürli, R. W.; Hughes, S. J.; Jarvis, R. E.; Lamers, M.; Leonard, P. M.; Matthews, K. L.; McAllister, G.; Pollack, S.; Saville-Stones, E.; Wishart, G.; Yates, D.; Dominguez, C. ACS Med. Chem. Lett. 2016, 7, 34-39. https://doi.org/10.1021/acsmedchemlett.5b00302

31. Asfaha, Y.; Schrenk, C.; Alves Avelar, L. A.; Lange, F.; Wang, C.; Bandolik, J. J.; Hamacher, A.; Kassack, M. U.; Kurz, T. Bioorg. Med. Chem. 2020, 28, 115108.

https://doi.org/10.1016/i.bmc.2019.115108

32. Wagner, F. F.; Weïwer, M.; Steinbacher, S.; Schomburg, A.; Reinemer, P.; Gale, J. P.; Campbell, A. J.; Fisher, S. L.; Zhao, W.-N.; Reis, S. A.; et al. Bioorg. Med. Chem. 2016, 24, 4008-4015. https://doi.org/10.1016/j.bmc.2016.06.040

33. Chekler, E. L. P.; Pellegrino, J. A.; Lanz, T. A.; Denny, R. A.; Flick, A. C.; Coe, J.; Langille, J.; Basak, A.; Liu, S.; Stock, I. A.; Sahasrabudhe, P.; Bonin, P. D.; Lee, K.; Pletcher, M. T.; Jones, H. L. Chem. Biol. 2015, 22, 15881596.

https://doi.org/10.1016/i.chembiol.2015.10.013

34. Hai, Y.; Christianson, D. W., Nat. Chem. Biol. 2016, 12, 741-747.

https://doi.org/10.1038/nchembio.2134

35. Borowiecki, P.; Bretner, M. Tetrahedron Asymmetry 2013, 24, 925-936. https://doi.org/10.1016/j.tetasy.2013.06.004

36. Gradilone, S. A.; LaRusso, N. F. Treatment of polycystic diseases with an HDAC6 inhibitor. US2015/0119413A1, 2015.

37. Diedrich, D.; Hamacher, A.; Gertzen, C. G. W.; Alves Avelar, L. A.; Reiss, G. J.; Kurz, T.; Gohlke, H.; Kassack, M. U.; Hansen, F. K. Chem. Commun. 2016, 3219-3222. https://doi.org/10.1039/C5CC10301K

38. Marson, C. M.; Savy, P.; Rioja, A. S.; Mahadevan, T.; Mikol, C.; Veerupillai, A.; Nsubuga, E.; Chahwan, A.; Joel, S. P. J. Med. Chem. 2006, 49, 800-805. 
https://doi.org/10.1021/im051010j

39. Liguori, A.; Sindona, G.; Romeo, G.; Uccella, N., Synthesis (Stuttg). 1987, 168-168.

https://doi.org/10.1055/s-1987-27874

40. Dines, J. A.; Marson, C. M. Tetrahedron 2016, 72, 8584-8592.

https://doi.org/10.1016/j.tet.2016.11.039

This paper is an open access article distributed under the terms of the Creative Commons Attribution (CC BY) license (http://creativecommons.org/licenses/by/4.0/ 